\title{
FORGING BY HAMMERING ON COPPER BETWEEN CRAFTSMANSHIP
} AND CREATIVITY

\author{
Salah Shaaban Hassanin ABDEL RAHMAN *
}

Department of Sculpture, Faculty of Fine Arts, Luxor, South Valley University, Egypt

\begin{abstract}
Minerals are one of the most abundant elements in nature, and they have a strong and distinctive presence and influence in civilization. Humanity, as its multiple capabilities have contributed to the realization of many achievements, starting with simple metal tools To the strong compounds, the discovery of minerals is a revolution in the history of the development of human thought, as it moved from the era of The use of stones to the era of using minerals and the subsequent discovery of their strength and uniqueness, and one of the most important minerals Copper metal, which was used in the past in the manufacture of weapons and tools, had great effects in industrial development And utensils, as it was also used in the field of arts, as the ancient Egyptian artist used it in the molding of artworks And converting it to the ore bronze, and the use of copper ore in the technical field has gone through many stages of development, as The Coptic artist and Islamic artist used it to make brass vessels and lamps, which were not used For the utilitarian purpose only, but the artist has combined it with many artistic inscriptions of motifs and themes that abound in both Of those arts, Coptic and Islamic art left us with a great legacy of these copper artworks, which It was rich in artistic and aesthetic values, and the use of this noble material did not end with the end of those ages, but rather it was inherited.

Keywords

Forging, Hammering, Copper, Craftsmanship, Creativity.
\end{abstract}

\section{Introduction}

Children and it became one of the famous crafts that the modern Egyptian artist cared about, as copper forming by scratching became Or in the ways a kind of modern artistic creativity, and the Egyptian artist, especially in the Khan Al-Khalili region, excelled In copper works, As the children excelled in drawing inspiration from their great artistic legacy in that material, and this creativity was not limited to On the artisanal artist only, but extended to the art academies, where he began to use that material in art colleges, The academic artist specialized in technical colleges developed the use of the material, so instead of forming by scratching, he used Roads on various copper foil, to provide us with wonderful artworks testifying to the ability of the contemporary Egyptian artist to Presenting a new artistic thought, drawing on its artistic and cultural heritage, and keeping pace with the global artistic development with its doctrines.

Artistic and creative, and the research provides a study of the development of the craft of copper forming and its role in preserving the cultural heritage and how to draw inspiration from the vocabulary of the Egyptian heritage in creating new artworks that carry and preserve the Egyptian spirit Authenticity and national identity.

\footnotetext{
*Corresponding author: finearts@fart.luxor.edu.eg
} 


\section{Research problem}

1- Raw materials are widely available in nature, including metals and other ores, but a hand that extends to extract These treasures are presented to serve humanity

2- The use of copper ore in technical processes has gone through many stages and many developments since ancient times.

Shed light on these stages and study them to learn how to develop and benefit from them in a manner suitable for the modern era.

\section{- Research aims :-}

1- The research aims to shed light on the role of the material as a material mediator in the transfer of ideas and artistic visions and the recording of The stages of a person's life and his thoughts throughout his artistic ages.

2- The research seeks to uncover the role of copper ore in enriching the prominent art of sculpture throughout the ages through Shaping it in different ways.

- Research hypotheses :-

1- The researcher assumes that the many properties and characteristics of the copper ore make it one of the most enriching ores for the artistic movement.

Both ancient and modern, because of their aesthetic and plastic values.

2- The researcher assumes that the formation of copper ore by methods passed through many stages through different ages, which made it transformed

From craft to a kind of artistic creativity.

\section{- Search limits :-}

1- Temporal boundaries: The researcher deals with examples of Egyptian art throughout all of its ages.

2- Spatial boundaries: Models from inside Egypt.

\section{Research Methodology:}

Analytical History.

Where the researcher studies models for the development of the craft of roads on copper through the ages and their role in enriching the art of sculpture Notable, as well as its impact on the development of the modern art movement in Egypt.

Copper ore components and types:

The raw material is the material found in nature, which a person must intervene as a medium 
to detect it.

It does not acquire an artistic form and becomes an aesthetic material until after the artist's hand has extended to it and made it feel Aesthetically "(1) Therefore, the material is the mediator between the creative imaginations of the soul and the material embodiedPainted physical works, copper ore has been considered throughout the ages as one of the metals that attracts artists and has an appearance My beauty raises their artistic imaginations, and it is one of the most important and most common and used metals in our time.

Copper ore malachite azurite, chrysocolla, copper sulfide, and copper ores that were used in Narrow-scale extraction of copperite, tenorite, bronite, chalcocite, coflite and copper sulfide It has been recognized since ancient times, and has been used in many diverse works in the field of metal forming.

With many properties including plasticity, hardness, elasticity, ductility, hammering, mechanical resistance and conductivity.

Al-Jeed for electricity, and copper is found in many forms, the most important and common of which are red copper and brass.

Copper is a very resistant noble metal To rust.

It is one of the most productive minerals due to the wide range of uses, and one of its most important properties is that it is a "flexible plastic metal."

For drawing and hammering, it can be formed in many ways, such as hammering or pressing without chances of breaking, and has a superficial, attractive and lustrous appearance after polishing, and it can also be colored Thermoforming and oxidation. Red copper has the advantage of being reliable for operation It is an alloy of red copper and zinc, and it is distinguished by its ease of casting - (brasses): - brass And its operation and high resistance to corrosion in water and air, it is suitable for forming and welding with silver and tin, which is cheaper The price of red copper is more widely used in industries because it is easy to form by pressing, hammering, and turning.

It can be operated on cold and is subjected to cracking if it is bent on the protector, and to color it ferment by heating it to a red color the gloomy.

\section{Methods of forming copper:}

The copper ore has many properties and properties, and this has contributed to the multiplicity of methods of forming this material. Methods One of the most important of these methods, and it is done either cold or hot, as well as using compression in presses For forming copper, and among the common methods is also cutting, hollowing, welding and assembling parts, but it must be done before starting Copper forming is prepared for forming. 


\section{Results and Recommendations:}

1- Hammering on copper is one of the most important art of prominent sculpture in Egypt, both ancient and modern. Interest in this art from the state and scientific academies.

2- The formation of copper and metals has gone through many stages of development through different ages, so this must be studied The stages, memorize them, and work to develop them in accordance with the modern era.

3- Crafts and craftsmen have had a great role in preserving many heritage industries, including the formation of Copper and metals, so attention must be paid to small crafts and help craftsmen to continue and develop.

4- The contemporary Egyptian artist has succeeded in blending the traditional and contemporary spirit in producing the art, so it is necessary Interest in studying the history of arts, crafts and small industries to contribute to their development and preservation.

\section{References}

1-Ahmed Fouad Salim: An Eyewitness to the Contemporary Egyptian Art Movement, Egyptian General Book Authority 2008

2-Alfred Lucas - translated by Zaki Iskandar: Materials and Industries of the Ancient Egyptians, The Egyptian Book House, Cairo

3-Jerome Stollentz: Translated by Fouad Zakaria: Art Criticism - An Aesthetic and Philosophical Study, Egyptian General Authority

For the book, Cairo 1981

4-Jamil Abdel Majid Fouad, Metals, The Arab Thought House, 1951

5-Samir Shushan: Metal Forming Technology, Dar Al-Hadary for Printing and Publishing, Alexandria 2007

6-Saleh Rida: The New Expressionized Narrative in the Works of the Artist Qassem Hussein, The National Center Exhibition Catalog

Fine Arts 1987

7-Margaret Meri - translated by Muharram Kamal: Egypt and its Eternal Glory, The Thousand Book Series, The Arab Statement Committee

8-Mona Kamel Al-Essawi: From the Folklore Mineral Artifacts, Ain for Humanitarian Studies and Research 2008

9-Mahmoud Bakshish: “Article” by Muhammad Rizk between Iron and Copper, Al-Hilal Magazine, Issue, March 2000, Dar

Crescent Publishing 
10-Nemat Ismail Allam: Arts of the Middle East from the Greek Conquest to the Islamic Conquest, Dar Al Ma'arif

11-Kamal al-Malakh: "Jamal al-Sajini”" series, Description of Modern Egypt, SIS, Cairo 12- Safaa Abdel Aziz Sabry ISMAIL, A CHILD'S CREATIVE IMAGINATIVE ABILITY THROUGH EXPERIMENTING WITH HAND-PRINTING, International Journal of Multidisciplinary Studies in Art and Technology, Vol. 1, No. 1, 2018, pp. 1-3.

13- Hoda Ali Ahmed Mohamed MADANI, AESTHETIC VISION AND CREATIVE IN ISLAMIC CERAMICS AND ITS IMPACT ON SOME CONTEMPORARY POTTERY WORKS, International Journal of Multidisciplinary Studies in Art and Technology, Vol. 1, No. 1, 2018, pp. 4-6.

Received: August 10, 2018

Accepted: October 2, 2018 